OPEN ACCESS

Edited and reviewed by: Chao Deng, University of Wollongong, Australia

*Correspondence: Francisco F. De-Miguel ffernand@ifc.unam.mx

Received: 28 November 2017 Accepted: 29 November 2017 Published: 12 December 2017

Citation:

De-La-Rosa Tovar A, Mishra PK and De-Miguel FF (2017) Corrigendum: On the Basis of Synaptic Integration Constancy during Growth of a Neuronal Circuit.

Front. Cell. Neurosci. 11:399. doi: 10.3389/fncel.2017.00399

\section{Corrigendum: On the Basis of Synaptic Integration Constancy during Growth of a Neuronal Circuit}

\author{
Adriana De-La-Rosa Tovar, Prashant K. Mishra and Francisco F. De-Miguel* \\ Instituto de Fisiología Celular-Neurociencias, Universidad Nacional Autónoma de México, Ciudad de Mexico, Mexico
}

Keywords: electrical coupling, synapse, leech, integration, passive conduction, development, growth

\section{A corrigendum on}

On the Basis of Synaptic Integration Constancy during Growth of a Neuronal Circuit by De-La-Rosa Tovar, A., Mishra, P. K., and De-Miguel, F. F. (2016). Front. Cell. Neurosci. 10:198. doi: 10.3389/fncel.2016.00198

Correction to the acknowledgments:

Adriana De-La-Rosa Tovar and Prashant Kumar Mishra were Doctoral Students of the Doctorado en Ciencias Biomédicas at the Universidad Nacional Autónoma de México.

The original article has been updated.

\section{ACKNOWLEDGMENTS}

We wish to express our gratitude to Mr. Bruno Mendez Ambrosio and Mr. Francisco Perez for their excellent technical assistance during this study and to Mrs. Sara Flores González for her invaluable assistance in the animal and laboratory care. AD-L-RT and PKM were Doctoral Students of the Doctorado en Ciencias Biomédicas at the Universidad Nacional Autónoma de México. This work was funded by a Dirección General de Asuntos del Personal Académico (DGAPA) grant IN200914 from the Universidad Nacional Autónoma de México (UNAM) and grant 130031 from the Consejo Nacional de Ciencia y Tecnología (CONACyT) to FFD-M.

Conflict of Interest Statement: The authors declare that the research was conducted in the absence of any commercial or financial relationships that could be construed as a potential conflict of interest.

Copyright $(2017$ De-La-Rosa Tovar, Mishra and De-Miguel. This is an open-access article distributed under the terms of the Creative Commons Attribution License (CC BY). The use, distribution or reproduction in other forums is permitted, provided the original author(s) or licensor are credited and that the original publication in this journal is cited, in accordance with accepted academic practice. No use, distribution or reproduction is permitted which does not comply with these terms. 